\title{
Internetezési szokások és etikai értékrend közötti lehetséges összefüggések vizsgálata közgazdászhallgatók körében
}

\section{Connection between internet using habits and ethical attitude of business students}

\author{
E. BARIZSNÉ HADHÁZI, ZS. KISS
}

Debreceni Egyetem, Gazdaságtudományi Kar, Vezetés- és Szervezéstudományi Intézet, Vezetéstudományi Tanszék, barizsne.hadhazi.edit@econ.unideb.hu Debreceni Egyetem, Gazdaságtudományi Kar, Vezetés- és Szervezéstudományi Intézet, Emberi Erőforrás Menedzsment Tanszék, kiss.zsuzsanna@eccon.unideb.hu

Absztrakt. Napjainkban szemtanúi lehetünk annak a tendenciának, hogy milyen mértékben beépült mindennapjainkba az informatikai eszközök, és ezzel együtt az internet használta. Egyetemi oktatóként is azzal szembesülünk, hogy diákjaink egyre erôsebben kötődnek az informatika világához. Kutatásunkban éppen ezért azt tüztük ki célul, hogy megvizsgáljuk, mennyi időt és milyen céllal használják az internetet hallgatóink. Korábbi munkáinkban már elemeztük közgazdászhallgatók etikai attitüdjeit, jelen tanulmányunkban ezt a két kérdést megpróbáljuk együtt is körbejárni, arra keresve a választ, vajon van-e valamilyen összefüggés fiataljaink internetezési szokásai és etikai értékítélete között.

Abstract. In these days we are witnessing a trend of more and more using IT assets and the using of internet too. As teachers at the university we can see that our students also tied with a thousand threads to the IT world. Current research aims to explore the students' internet using habits, how many times they spend on the web and why. In our previous work we examined our economist students' ethical attitudes. In this study we try to connect this two themes. Our research question: are there any connection between our students' ethical judgment and their internet using habits.

\section{Bevezetés}

Tanulmányunkban két témakör összekapcsolására vállalkozunk, részben elemezni szeretnénk egyetemi hallgatóink internetezési szokásait, részben pedig csalással kapcsolatos attitűdjeiket.

Mind a hétköznapokban, mind pedig az oktatásban nyilvánvaló tény, hogy a diákok egyre több időt töltenek különböző informatikai eszközök használatával, legyen annak bármi oka is, hiszen ezek közül a világhálóra csatlakozva töltött idő csak egy a sok közül, ezen túl „okoseszközökön” olvasnak, zenét hallgatnak, filmet néznek, játszanak, vásárolnak, esetleg tanulnak, stb. 
Az etikai attitűd témaköre szintén egyetemi oktatóként került érdeklődésünk fókuszába, hiszen nap mint nap látjuk, hogy a hallgatók sajnos igen gyakran élnek tanulmányaik ideje alatt a csalás különböző formáival és ebben az internet igen nagy segítségükre van.

E két tárgykört szándékoztunk összekötni egy rövid kérdőívvel, amelyet a Debreceni Egyetem Gazdaságtudományi Kar hallgatói körében töltettünk ki. Kutatásunk első fázisának eredményeiről szeretnénk most beszámolni, mind a mintavétel nagyságára és a kérdések összetételére vonatkozóan ugyanis további terveink vannak. Azonban azt gondoljuk, hogy az első körben visszaérkezett adatok elemzése is ad számunkra egy képet a hallgatók fent említett két témakörben megfigyelhető magatartásáról.

\section{Szakirodalmi áttekintés}

Első témakörünk a hallgatók internetezési szokásait tekinti át, ehhez a 2015. évre készített lakossági internethasználatra vonatkozó szokásokat feltáró online piackutatás adatait vettük figyelembe [13]. A kutatás adatai szerint 2015-ben a megkérdezettek körében az internetképes eszközök birtoklása terén az okostelefon áll az élen. Korcsoportokat tekintve az adatokból kiderül az is, hogy a 20-29 éves korosztály napi 7 órán keresztül kapcsolódik az internetre és ebből 4,1 órát annak aktív használatával tölt, ez valamennyi korosztályt figyelembe véve a legmagasabb értékeket jelenti mindkét vonatkozásban. Az internetezési összidő 37\%-át teszi ki az e-mailezés, böngészés, míg a többi vizsgált tevékenység (csetelés, zenehallgatás, tévé-, video- és filmnézés, egyszerű játék vagy gémezés1) az azt végzők körében (egyénenként) a 25-30\%-át fedi le a teljes napi internetezési időnek. A középiskolai tanulók, illetve a főiskolai, egyetemi hallgatók 74\%-a használja az internetet a tanintézményben (akár szünetben, vagy például unalmas órán is). Megfigyelhető az a tendencia is, hogy az okostelefon alkalmas a tétlen várakozás idejének kitöltésérre is (sorban állás, de akár evés közben, szórakozóhelyen stb.) [13].

A hallgatók etikai attitűdjeivel kapcsolatban mind nemzetközi, mind pedig hazai kutatásokat meg kell említenünk. A nemzetközi vizsgálatok közül kiemelkedőnek tekinthető McCabe munkássága, aki munkatársaival számos aspektusból vizsgálta 1960-tól napjainkig egyetemi hallgatók csalással kapcsolatos attitűdjeit. McCabe munkacsoportja két irányban végzett kutatásokat: egyrészt egyetemi hallgatók csalással kapcsolatos magatartásformáit próbálták feltárni, másrészt megkísérelték az ezeket befolyásoló tényezőket is azonosítani. McCabe és Trevino mutatta ki azt, hogy 1963-hoz képest 1993-ra az amerikai egyetemisták körében 26\%-kal nőtt azok aránya, akik dolgozatírás közben társukéról másoltak, 38\%-kal nőtt azok aránya, akik csoportokban dolgoztak, annak ellenére, hogy a tanár egyéni munkát kért tőlük, illetve azt, hogy ugyanezen hallgatók körében 4\%-kal csökkent a plagizálás aránya [11]. A befolyásoló tényezők közül a nemeket alapul véve McCabe és Bowers mutatta ki azt, hogy a vizsgált 30 éves periódusban 7\%-kal nőtt a nők csalási rátája, míg a férfiaké állandó maradt (ennek oka lehet az, hogy több nő vesz részt napjainkban a felsőoktatásban, de az is, hogy a

\footnotetext{
${ }^{1}$ Tipikusan a szerep-, akció- és stratégiai játékokat sorolhatjuk ide, amelyek használatának megtanulása hosszabb időt igényel, nagyobb a hardverigénye, komplex világot jelenít meg, színvonalas grafikával.
} 
nőket a férfiakkal folytatott verseny kényszeríti rá a csalásra, nem pusztán ők maguk ennyire etikátlanok) [9]. McCabe és Trevino azt is kimutatták továbbá, hogy ha a társak elfogadóak a csalással szemben, illetve ha szemtanúja egyik diák a másik csalásának, akkor nő a csalás előfordulása, illetve azt is megállapították, hogy a súlyos büntetéssel való fenyegetés hatása kétszer kisebb, mint a kortársak magatartásának befolyásoló ereje [10].

Az egyetemi etikai kódexekkel összefüggésben McCabe és munkatársai azt találták, hogy azon a campuson, ahol létezik az etikai kódex intézménye, ott a hallgatókban pozitív attitűd alakul ki a csalás monitorizálása, jelentése és kezelése során, így ezekben a felsőoktatási intézményekben kevesebbet csalnak a diákok. A kutatók szerint nagyon fontos hangsúlyozni, hogy a kódexek létezése önmagában azonban kevés, szükség van arra is, hogy az abban foglaltakat mind a hallgatók, mind pedig az oktatók magukévá tegyék, annál is inkább, mert a súlyos büntetés kilátásba helyezésével szemben ennek kétszer erőteljesebb hatását tudták igazolni [12].

A nemzetközi kutatások egy másik irányvonala, amelynek során azt vizsgálják, hogy egyetemi hallgatók mely munkahelyi szituációkat tartanak etikátlannak és milyen mértékben. E területen Ludlum és szerzőtársai munkájára építkezhetünk, akik elsőként orosz egyetemi hallgatók között próbálták felmérni, hogy mit gondolnak a korrupcióról és annak okairól [6]. Ludlum kutatásait 2009 őszén öt amerikai campuson is elvégezte, 2015-ben pedig megismételte, igaz, már csak három campust vizsgálva. Ezen empirikus felmérések során a hallgatóknak 20 munkahelyi szituációt kellett egy ötfokozatú Likert-skálán megítélni aszerint, hogy mennyire tartják etikusnak. A diákok négyet ítéltek különösen etikátlannak: megvádolni egy ártatlan kollégát azzal, amivel minket vádolnak; nyilvánosságra hozni a titkos információkat; valaki más munkájáért learatni a babérokat és jelentést hamisítani, ezekre az átlagérték nagyobb lett, mint négy [7] és [8].

A nemzetközi kutatásokban egy másik kérdés, amire a szakértők választ szeretnének kapni, hogy a hallgatók etikai értékrendje befolyással van-e későbbi munkahelyi viselkedésükre. Erre igenlő választ adott Sims 1993-as tanulmánya [15]. Ugyanakkor utalnunk kell arra a vizsgálati eredményre is, miszerint a hallgatók etikai tanulmányai nem befolyásolják tetteiket, morális és immorális választásaikat [2] és [16].

A hazai szakirodalomban mindezidáig csupán két szerző munkáiban találkoztunk a diákok csalási szokásaira vonatkozó elemzésekkel.

Egyikük Fülöp Márta, aki a versengő magatartással kapcsolatban elemzi az etikus viselkedést [4]. Egyik tanulmányában megállapítja, hogy a magyar diákok többet csalnak, mint külföldi társaik, ugyanakkor két érdekes tényre is felhívja a figyelmet, egyrészt, hogy a magyar iskolákban csak az oktató által észrevett csalást kezeljük, másrészt pedig, hogy amennyiben egy diák jelzi a csalást a tanárnak, akkor gyakori reakció a pedagógus részéről a „foglalkozz a magad dolgával” típusú válasz [4].

Másik hazai szerző ebben a témában Orosz Gábor, aki 2011-ben megjelent tanulmányában leírja, hogy a diákok többsége elfogadhatónak tartja a lesést, rendszeresen szokott lesni számonkéréseken, illetve hagyja, hogy mások lessenek a dolgozatáról, holott kétharmaduk tisztában van azzal, hogy ilyen esetekben csalásról van szó [14]. 
Saját kutatásaink közül kettőre utalnánk most vissza. Egyikben azt vizsgáltuk (Ludlum kutatásaira építve kérdéseinket), hogy a Debreceni Egyetem Gazdaságtudományi Kar hallgatói hogyan ítélnek meg konkrét munkahelyi magatartásformákat azok etikai tartalmát illetően. A Kar diákjainak megítélése szerint 9 olyan állítás volt, amelyik a különösen etikátlan kategóriába tartozik (ahol az átlag 4 fölötti értéket mutatott). Többek között: a titkos információk nyilvánosságra hozatala, a minket ért vádakkal mások megvádolása, eltulajdonítani a cég eszközeiből, más munkájának babérjait learatni, a jelentések meghamisítása, a munka közbeni alvás, a céges szabályzatok megszegésének engedélyezése, a számlák 10\%-nál nagyobb értékű növelése és a templomban alvás azok a magatartások, amelyek hallgatóink meglehetôsen etikátlannak tartanak [1].

Egy másik kutatásunkban a most bemutatni kívánt elemzés előzményeit foglaltuk össze. Ennek során a 2. táblázatban leírt eredményeket találtuk, mivel ezekről a későbbiekben még lesz szó, itt most csak rövid áttekintést adunk korábbi eredményeinkről: végkövetkeztetésként elmondhatjuk, hogy a felmérésben részt vevő diákok magát a csalást, a plágiumot felismerik, hiszen, ahogyan a 2. számú táblázata is mutatja, szinte minden szituációt a válaszadók több mint 90\%-a etikátlannak tart. Ugyanakkor azok komolyságát tekintve már elnézőbbek az elkövetett etikátlan magatartásformákkal szemben: a csalás komolyságának átlagos értéke sehol sem érte el a 4-es értéket.

A fenti irodalmak áttekintése után térjünk át jelen kutatásunk módszertanának bemutatására, ezután pedig ismertetjük legfontosabb kutatási eredményeinkkel, melyek érdekesek lehetnek valamennyi felsőoktatásban dolgozó oktató számára.

\section{Adatok és módszer}

Empirikus kutatásunk ötletét Katie Lozier diplomamunkája adta (Ball State University 2012), aki különböző tényezők függvényében vizsgálta egyetemi hallgatók csalási szokásait oly módon, hogy a diákoknak az általa leírt néhány mondatos szituációkat kellett minősíteni aszerint, hogy csalásnak vélik-e, és ha igen, milyen mértékben. Tanulmányának első olvasása után született meg az az elhatározásunk, hogy egy ehhez hasonló kérdőív segítségével a Debreceni Egyetem Gazdaságtudományi Karának hallgatói körében is érdemes lenne kutatásokat végezni. Maga a módszer már önmagában is érdekes, hiszen azon túl, hogy elemezhetőek ezen szituációk segítségével diákjaink csalásra vonatkozó attitűdjei és szokásai, atekintetben is információkat szolgáltat, hogy a napjainkban zajló technológiai változások mennyiben változtatják meg a csalási szokásokat, ezek közül melyekre érdemes figyelnie az oktatóknak, nem mellesleg az egyetem(ek) által kidolgozott etikai kódexekbe milyen új magatartásformákat érdemes felvenni és szabályozni. Munkánk során arra keressük a választ, hogy hallgatóink mennyi időt szánnak napjaikból internetezésre és azt milyen céllal teszik, illetve megpróbálunk összefüggéseket keresni internetezési szokásaik és etikai értékrendjük között. Azaz van-e statisztikailag is igazolható kapcsolat az internetezési szokások egyes elemei és aközött, hogy milyen cselekedeteket ítélnek meg csalásként és milyen mértékben.

Az általunk összeállított kérdőív eltér az eredeti, Lozier által használt kérdőívtől, hiszen az értékelendő szituációkat módosítanunk kellett, azaz adaptáltuk őket a magyar egyetemi oktatásban jellemző szituációkhoz. Ennek eredményeképpen kérdőívünk 10 szituációt tartalmazott, míg az eredeti 
kutatásban két kérdőív készült 10-10 különböző helyzetleírással. A kérdőívek kitöltésére 2016. tavaszán került sor.

A kérdőív első része demográfiai adatokat kért a válaszadóktól (nem, szak, tagozat, évfolyam), a második részben internetezési szokásaikról vártunk információkat. Megkérdezetteink választ adtak arról, hogy mennyit interneteznek naponta általában és különböző céllal: tanulmányi, kapcsolattartási, vásárlási és játék céljából (1 óránál kevesebbet, 1-3 óra között, 3-5 óra között, 5-7 óra között, 7 óránál többet). Nyilatkoztak továbbá arról is, hogy saját megítélésük szerint milyen mértékben kezelik fair módon az internetet, ismerik-e egyetemünk etikai kódexét, könnyü-e használni az internetet az egyetemen kapott feladatok során, egyetértenek-e azzal, hogy a legtöbb diák legalább egyszer csal egyetemi tanulmányai során, illetve azzal, hogy a tanárok nehezebben veszik észre az internetes csalásokat. Mindkét befolyásoló tényező csoport differenciálása során öt előre kialakított kategória közül kellett válaszolni hallgatóinknak, amelyek így megfeleltethetőek egy-egy ötfokozatú Likert skálának. A csalással kapcsolatos szituációk értékelése során a diákok arra választoltak, hogy csalásnak számít-e szerintük a bemutatott tevékenység (igen és nem válaszlehetôség), s ha igen, akkor mennyire súlyos szerintük a csalás ( 5 fokozatú Likert-skálán megjelölve, ahol az $1=$ nem komoly és az 5 = nagyon komoly).

Kérdőívünket 61 fő töltötte ki, közülük 44 nő és 17 férfi, nappali tagozaton tanul 66\%-uk, levelező tagozaton 34\%-uk. Alapszakos diák a válaszadók 61\%-a, mesterszakos tanuló a kitöltők 34\%-a, a hallgatók 5\%-a nem adta meg, hogy milyen képzési szinten tanul a Karon. Kutatásunk nem tekinthető reprezentatív felmérésnek, a minta elemszáma is viszonylag alacsony, ebből kifolyólag munkánkat további kutatások alapjainak tekinthetjük, mindamellett, hogy bizonyos következtetések megfogalmazására önmagában is alkalmas.

Eredményeink bemutatása során áttekintjük, hogy a hallgatók milyen internetezési szokásokat alakítottak ki, bemutatjuk az egyes szituációk értékelését is, végül pedig összefüggéseket keresünk kutatásunk e két dimenziója között.

Az elemzések során átlagot, szórást számolunk a Likert-skálákon adott válaszok értékét figyelembe véve, illetve a teljes mintát tekintve Pearson-féle, illetve Spearman-féle korrelációs mutatót vizsgálunk az egyes kérdések közötti összefüggések bemutatására. A korrelációs együttható értékét Evans (1996) alapján a következők szerint értelmezhetjük:

- $0.00-0.19$ : nagyon gyenge

- $0.20-0.39$ : gyenge

- $0.40-0.59$ : közepes

- $0.60-0.79$ : erős

- 0.80 - 1.0 : nagyon erős kapcsolat a vizsgált tényezők között [18].

Tekintsük át ezek után az empíria legfontosabb eredményeit.

\section{Eredmények}


Empirikus adatbázisunk elemzését a hallgatók internetezési szokásainak bemutatásával kezdjük.

A diákok előzetes várakozásainkhoz képest meglepően szerényen nyilatkoztak a napi internethasználattal kapcsolatban. Ahogyan azt az 1. ábrán is láthatjuk, a Kar megkérdezettjei legnagyobb arányban 1 és 3 óra közötti időt töltenek naponta általában internethasználattal, de ettől csak néhány százalékkal maradt el a 3 és 5 óra közötti időintervallumra adott válaszolók aránya. Összességében tehát azt állapíthatjuk meg, hogy a hallgatók körülbelül 60 \%-a egy napjának 24 órájából hármat valamilyen formában a világhálóra kapcsolódva tölt el.

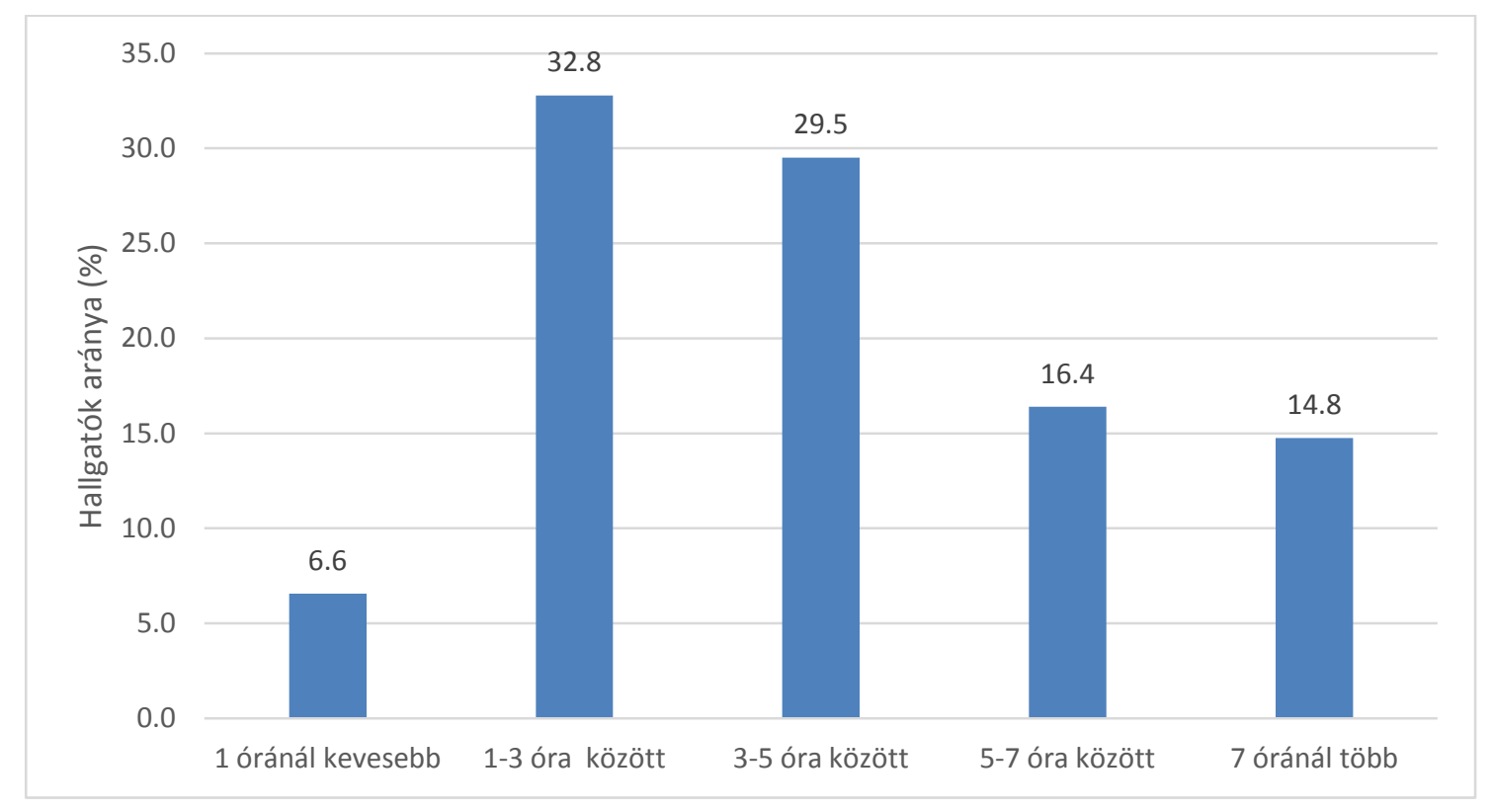

1. ábra: Internethasználat általánosan naponta

Nézzük meg a továbbiakban, hogy milyen célokra fordítják ennek az időnek egyes részeit a diákok (2. ábra).

Tanulmányi célokra a hallgatók összesen 37,7\%-a használja egy óránál kevesebb időtartamban az internetet, míg 49,2\%-uk egy és három óra közötti időt jelölt meg. Összességében tehát azt mondhatjuk, hogy ez a csoport a hallgatók 86,9\%-a, ami elég magas arány, ennél több időt tanulmányi célokra viszonylag kevesen fordítanak. 


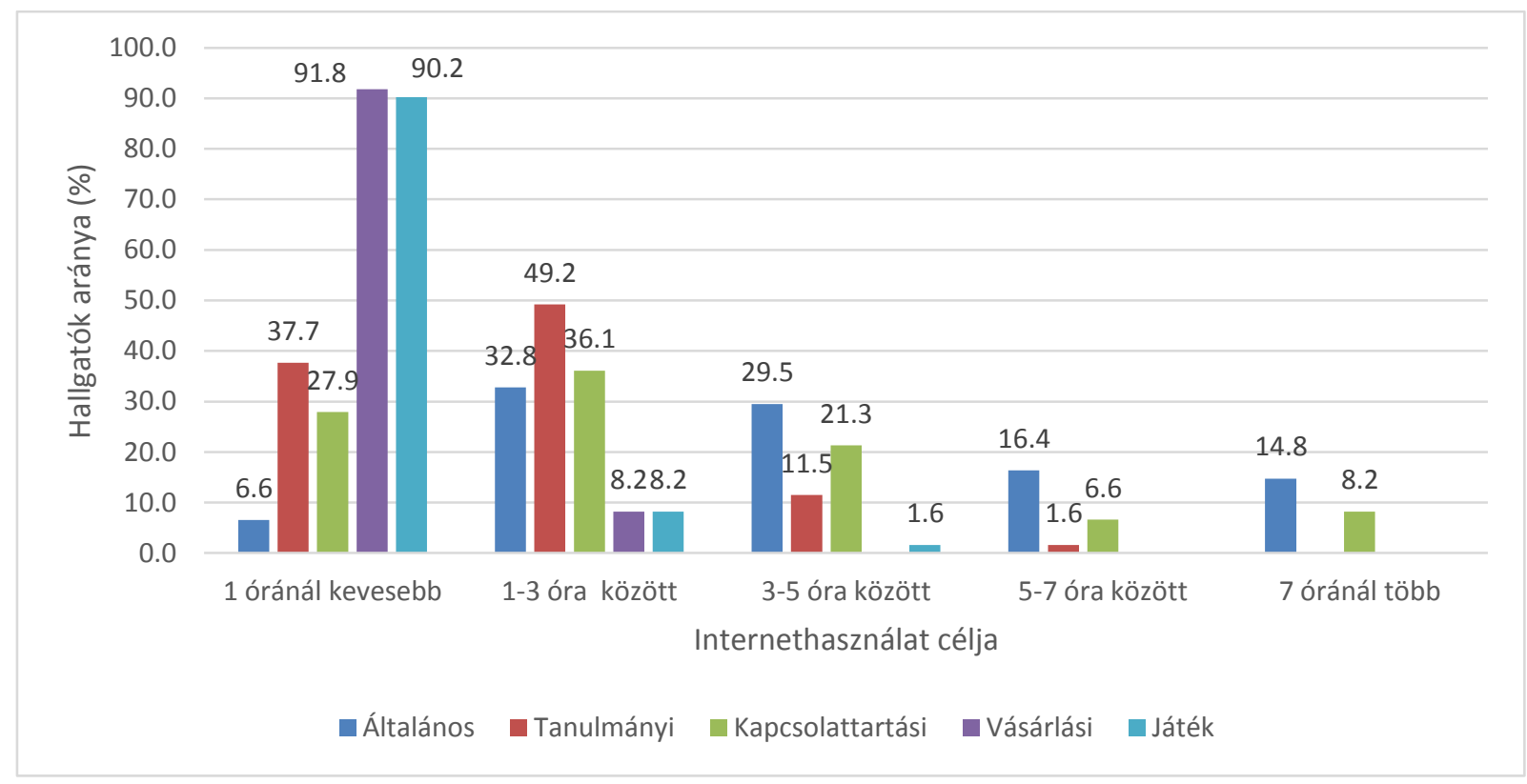

\section{2. ábra: Az internethasználatra fordított idő annak célja szerint}

Kapcsolattartási célok esetében már jobban megoszlott a válaszadók véleménye: legtöbbjük (36,1\%) egy és három óra között, míg 27,9\%-uk kevesebb, mint egy órát tölt internetre csatlakozva ezzel a céllal, 21,3\%-uktól pedig három és öt órát vesz el ez a tevékenység. A kapcsolattartási cél esetében elmondhatjuk tehát, hogy hallgatóink körében ez több, mint amit tanulási céllal a világhálóra csatlakozva töltenek el.

Az internethasználattal töltött időből viszonylag kevés időt fordítanak diákjaink a világhálón vásárlással, 91,8\%-uk egy óránál kevesebb, míg 8,2\%-uk egy és három óra közötti időt jelölt meg válaszként.

A játék céljából történő internethasználat esetében is mindannyian maximum öt órát jelöltek meg, a hallgatók 9/10-e egy óránál kevesebbet, 8,2\%-a egy és három óra közötti, míg 1,6\%-a három és öt óra közötti időtartamot. Feltételezéseink szerint ennek magyarázata abban rejlik, hogy ebben a korosztályban már csak egy kisebb csoportot vonzanak a számítógépes játékok rendszeresen, ezek a játékok a fiatalabb korosztály körében népszerűbbek.

Megkértük hallgatóinkat arra is, hogy az 1. táblázatban felsorolt állításokat is értékeljék aszerint, hogy mennyire tartják azt magukra jellemzőnek, illetve mennyire értenek egyet az adott állítással22, vizsgálni szerettük volna ugyanis ezen tényezők esetleges befolyásoló hatását etikai értékrendjükre. Összességében elmondhatjuk, hogy diákjaink egy ötfokozatú Likert skálán mérve átlagosan 4,2 értéknek megfelelően vélték önmagukra nézve igaznak azt, hogy fair módon kezelik az internetet (szórás 0,792), azaz magukról egészen pozitív képet alkotnak e tekintetben. Közepesnél kisebb mértékben vallották azt, hogy jól ismerik az egyetem etikai kódexét (átlag 2,56 és 1,009 szórás mellett), ez véleményünk szerint eléggé alacsony érték, szomorú, hogy etikai kódexünket ilyen kevéssé

${ }^{2}$ A válaszadásra egy ötfokozatú Likert skálán volt lehetőségük, ahol az 1 = Egyáltalán nem jellemző rám/Egyáltalán nem igaz, míg az 5 = Nagyon jellemző rám, Teljes mértékben igaz tartalommal bírt. 
ismerik, olvassák vagy alkalmazzák tanulmányaik során. Közepes mértékben gondolják úgy, hogy könnyű az internetet használni az egyetemi feladatok megoldása vagy a tesztek/vizsgák megírása során (átlag 2,95 és szórás 1,126). Ennél magasabb átlagértéket $(3,66)$ kaptunk akkor, amikor azt kérdeztük, hogy mennyire igaz az, miszerint a legtöbb diák legalább egyszer csal egyetemi tanulmányai alatt feladatmegoldás során vagy vizsgaszituációban. Ez a válasz szintén sötét képet fest a hallgatók etikai értékrendjéről, beleértve azt is, hogy erre részben az ő hajlandóságuk, részben pedig az oktatók hozzáállása ad lehetőséget. Hallgatóink véleménye szerint közepesnél kicsit alacsonyabb mértékben igaz az, hogy a tanároknak nehezebb dolguk van az internetes csalások felismerésében (átlag 2,67). A szórás értékeire is vessünk egy pillantást: valamennyi állítás esetében 1 körül mozog ennek értéke, ami arra utal, hogy diákjaink értékítélete nem szóródik túlságosan, megítélésük ezen állításokra vonatkozóan nagyon hasonló.

\begin{tabular}{|l|c|c|}
\hline \multicolumn{1}{|c|}{ Állítás } & Átlagérték & Szórás \\
\hline Azt gondolom, hogy fair módon kezelem az internetet. & 4,2 & 0,792 \\
\hline $\begin{array}{l}\text { Teljes mértékben tisztában vagyok azzal, hogy az egyetemi etikai } \\
\text { kódex mit tartalmaz. }\end{array}$ & 2,56 & 1,009 \\
\hline $\begin{array}{l}\text { Könnyủ az internetet használni az egyetemen a feladatok } \\
\text { megoldása vagy a tesztek/vizsgák megírása során. }\end{array}$ & 2,95 & 1,126 \\
\hline $\begin{array}{l}\text { A legtöbb diák legalább egyszer csal az egyetemi tanulmányai alatt } \\
\text { a feladatokban vagy vizsgák megírása során. }\end{array}$ & 3,66 & 1,377 \\
\hline A tanároknak nehezebb észrevenni az internetes csalásokat. & 2,67 & 1,145 \\
\hline
\end{tabular}

1. táblázat: Egyéb befolyásoló tényezők átlag és szórás adatai

Az internetezési szokásokkal kapcsolatban két internetezési szokás együttmozgására is felfigyeltünk: azok a hallgatók, akik általánosságban többet interneteznek naponta azok leggyakrabban kapcsolattartási céllal teszik ezt (rho=0,536 1\% szignifikancia szint mellett).

A kérdőív következő része olyan szituációkat tartalmazott, amelyekkel kapcsolatban a megkérdezett hallgatóknak két kérdésre kellett válaszolniuk: elsőként arra, hogy csalásnak vélik-e a leírt cselekedetet, illetve ha igen, akkor milyen mértékben. Az első kérdésre igen vagy nem válasz volt lehetséges, míg a második kérdés esetében egy ötfokozatú skálán kellett megjelölniük, hogy milyen komoly csalásként tekintenek a szituációra $(1=$ nem komoly.......5 = nagyon komoly). A 2. táblázatban olvashatóak a legfontosabb eredmények, így a szituációk felsorolása mellett az is, hogy az egyes szituációkat a hallgatók milyen arányban minősítették csalásnak (a teljes mintát tekintve), akik pedig csalásnak vélték az adott szituációt, hogyan ítélték meg annak komolyságát (a Likert skála átlagértékei és szórása szemlélteti).

\begin{tabular}{|ll|c|c|}
\hline Szituáció sorszáma, rövid leírása & $\begin{array}{c}\text { Azon hallgatók aránya, } \\
\text { akik csalásnak } \\
\text { értékelték (\%) }\end{array}$ & $\begin{array}{c}\text { Átlagosan milyen } \\
\text { mértékben értékelték } \\
\text { csalásnak (szórás) }\end{array}$ \\
\hline 1. & $\begin{array}{l}\text { Egy társ beszédének szó szerinti } \\
\text { másolatának beadása }\end{array}$ & 100 & $3,77(1,3)$ \\
\hline 2. & Plágium & 90 & $3,76(1,3)$ \\
\hline 3. & Neten megtalált tesztmegoldás & 92 & $3,75(1,1)$ \\
\hline 4. & Beadandó vásárlása a neten & 95 & $3,74(1,3)$ \\
\hline 5. & Facebook-ról másolt eredmények & 98 & $3,45(1,4)$ \\
\hline
\end{tabular}




\begin{tabular}{|ll|c|c|}
\hline & benyújtása & & \\
\hline 6. & Telefonos csalás vizsga közben & 97 & $3,24(1,1)$ \\
\hline 7. & Torzított munkaidő-nyilvántartás & 93 & $3(1,1)$ \\
\hline 8. & Közös munka egyéni munka helyett & 59 & $2,72(0,9)$ \\
\hline 9. & Dolgozatírás közbeni lesés & 90 & $2,62(1)$ \\
\hline $\begin{array}{l}\text { 10. Önálló gondolatok nélkül elkészített } \\
\text { beadandó }\end{array}$ & 31 & $1,84(1)$ \\
\hline
\end{tabular}

2. táblázat: Az egyes szituációk értékelésének bemutatása

A részletes elemzésre nem térünk mivel ezt már másik tanulmányunkban megtettük ${ }^{3}$, itt pusztán két összefoglaló megállapítást teszünk, elsőként: a felmérésben részt vevő diákok magát a csalást, a plágiumot felismerték, hiszen, ahogyan a táblázata is mutatja, szinte minden szituációt a válaszadók több mint 90\%-a etikátlannak tartott. Másodikként ugyanakkor kijelenthetjük, hogy azok komolyságát tekintve már elnézőbbek az elkövetett etikátlan magatartásformákkal szemben: a csalás komolyságának átlagos értéke sehol sem érte el a 4-es értéket.

Ezen tanulmányunkban arra fókuszálunk, hogy az internetezési szokások és az egyes szituációk csalásként való megítélése között kimutatható-e valamilyen kapcsolat.

Tekintsük át, hogy a hallgatók internetezési szokásairól feltett kérdések és az egyes szituációk értékelése között milyen korrelációs kapcsolatokat tárhatunk fel. Elsőként megállapítható az adatokból, hogy a hallgatók tanulmányi céllal internetezéssel töltött ideje közepesen korrelál azzal, hogy mennyire tartják komoly csalásnak az önálló gondolatok nélkül benyújtott házi dolgozat elkészítése (rho=0,509 5\%-os szignifikancia szint mellett). Együtt mozog annak megítélése is, hogy a legtöbb diák legalább egy alkalommal csal egyetemi tanulmányai során és az, hogy valaki vizsgán telefonos segítséget vesz igénybe ( $\mathrm{r}=0,361$ 1\% szignifikancia szint mellett).

Megvizsgáltuk az előzőeken túl azt is, hogy az egyes szituációk értékelése milyen együttmozgásokat mutat, ennek eredményeit mutatjuk be az alábbiakban.

Gyenge korrelációt találtunk a következők állítások értékelése között:

- együtt jár annak megítélése, hogy a diákok a neten vásárolnak házi dolgozatot és az, hogy a hallgató torzítja a munkaidő-nyilvántartást a saját érdekében ( $\mathrm{r}=0,386$ 1\%-os szignifikancia szint mellett),

- együtt jár annak megítélése is, hogy valaki a Facebook-ra kiposztolt dolgozatról másolja le a megoldásokat és az, hogy torzítja a munkaidő-nyilvántartást saját érdekében ( $\mathrm{r}=0,378$ 1\%-os szignifikancia szint mellett).

Hasonlóan (közepesen) súlyos csalásként minősítették a megkérdezett hallgatók a következőket (lásd 3. táblázat):

- mennyire komoly csalás a plágium és az, hogy valaki neten vásárol meg egy beadandó dolgozatot $(r=-0,576$ 1\%-os szignifikancia szint mellett),

\footnotetext{
3 Megjelenés alatt, elfogadva a Taylor: Gazdálkodás- és szervezéstudományi folyóirat: A Virtuális Intézet Közép-Európa kutatására Közleményei 2017. évi számában.
} 
- mennyire komoly csalás a plágium és az, hogy vizsga írása közben telefonon segítséget kér egy diák ( $\mathrm{r}=0,494$ 1\%-os szignifikancia szint mellett),

- mennyire komoly csalás egy társunk beszédét szó szerint ugyanúgy beadni sajátunkként és az, hogy valaki vizsga közben telefonon segítséget kér ( $r=0,547$ 1\%-os szignifikancia szint mellett),

- mennyire komoly csalás egy társunk beszédét szó szerint ugyanúgy beadni sajátunkként és az, hogy mennyire komoly csalás a munkaidő-nyilvántartást saját érdekünkben torzítani $(\mathrm{r}=0,493$ 1\%-os szignifikancia szint mellett),

- mennyire komoly csalás egy önálló gondolatok nélkül elkészít beadandót benyújtani és a vizsga közben telefonon segítséget kérni ( $\mathrm{r}=0,528$ 5\%-os szignifikancia szint mellett),

- mennyire komoly csalás a neten vásárolt dolgozat benyújtása és a facebook-ra kiposztolt eredmények bemásolása ( $\mathrm{r}=0,5671$ szignifikancia szint mellett),

- mennyire komoly csalás, ha valaki vizsga közben telefonon kér segítséget és az, hogy mennyire komoly csalás dolgozatírás közben lemásolni más válaszait ( $\mathrm{r}=0,5351$ szignifikancia szint mellett)

- mennyire komoly csalás, ha valaki vizsga közben telefonon kér segítséget és az, hogy mennyire komoly csalás a munkaidő-nyilvántartás meghamisítása ( $\mathrm{r}=0,5681$ szignifikancia szint mellett).

Erős korrelációt találtunk a következő tényezők között:

- annak megítélése, hogy valaki plagizál és az, hogy a facebookra kiposztolt megoldásokat használja fel a hallgató ( $r=0,641 \%$ szignifikancia szint mellett),

- annak megítélése, hogy egy társ beszédét szó szerint beadjuk és az, hogy a hallgató neten vásárolja meg a beadandó dolgozatot ( $\mathrm{r}=0,6421 \%$ szignifikancia szint mellett).

\begin{tabular}{|l|l|l|l|l|l|}
\hline Szituációk & $\begin{array}{l}\text { Beadandó } \\
\text { vásárlása } \\
\text { a neten }\end{array}$ & $\begin{array}{l}\text { Facebook-ról } \\
\text { másolt } \\
\text { eredmények } \\
\text { benyújtása }\end{array}$ & $\begin{array}{l}\text { Dolgozatírás } \\
\text { közbeni lesés }\end{array}$ & $\begin{array}{l}\text { Telefonos csalás } \\
\text { vizsga közben }\end{array}$ & $\begin{array}{l}\text { Torzított } \\
\text { munkaidő- } \\
\text { nyilvántartás }\end{array}$ \\
\hline Plágium & $0,576^{* *}$ & & & $0,494^{* *}$ & $0,493^{* *}$ \\
\hline $\begin{array}{l}\text { Egy társ beszédének szó } \\
\text { szerinti másolatának } \\
\text { beadása }\end{array}$ & & & & $0,547^{* *}$ & $0,528^{*}$ \\
\hline $\begin{array}{l}\text { Önálló gondolatok nélkül } \\
\text { elkészített beadandó }\end{array}$ & & & & & \\
\hline Beadandó vásárlása a neten & & $0,567^{* *}$ & & $0,535^{* *}$ & \\
\hline Dolgozatírás közbeni lesés & & & & & $0,568^{* *}$ \\
\hline $\begin{array}{l}\text { Telefonos csalás vizsga } \\
\text { közben }\end{array}$ & & & & & \\
\hline
\end{tabular}

3. táblázat: Közepes mértékú korrelációs kapcsolatok ${ }^{4}$

Nagyon erős korrelációs találtunk a következő tényezők között:

- együtt jár annak megítélése, hogy valaki plagizál és az, hogy valaki a felsőbb évfolyamos hallgató korábbi beszédét változtatás nélkül adja be ( $\mathrm{r}=0,819$ 1\% szignifikancia szint mellett),

- együtt jár annak megítélése, hogy valaki szó szerint egy hallgató társának korábbi beszédét sajátjaként nyújtja be és az, hogy a facebookra kiposztolt eredményeket másolja le ( $\mathrm{r}=0,8131 \%$ szignifikancia szint mellett).

\footnotetext{
$4 * 5 \%$ szignifikancia szint mellett és ** $1 \%$ szignifikancia szint mellett
} 
A fentiekben bemutatott kutatási eredmények összegzéseként elmondhatjuk, hogy hallgatóink valamennyi értékelendő szituációban felismerték az etikai vétséget (több mint 90 százalékuk csalásként értékelte azt). A Lozier munkájában található elemzéssel összehasonlítva azonban azt látjuk, hogy az egyes szituációk megítélésében nem voltak olyan szigorúak, mint amerikai társaik, hiszen azok komolyságának értékelésekor egyetlen esetben sem érték el a 4 átlagot. A Lozier által megkérdezett hallgatók két kivételtől eltekintve (közös munka egyéni munka helyett és önálló gondolatok nélkül elkészített beadandó) minden szituációt súlyosabb csalásként értékeltek a magyar kutatáshoz képest.

\section{Zárszóként}

Tanulmányunkban egyetemi hallgatók internetezési szokásait és etikai attitűdjét vizsgáltuk a Debreceni Egyetem Gazdaságtudományi Karán. A hallgatók mindennapjainak igen fontos eleme lett a különböző okos eszközök használata, melynek során szinte a napjaik döntő részét internetre csatlakozva töltik el. Egyetemi oktatóként azt is gyakran tapasztaljuk, hogy az internet használata sok területen megkönnyíti a hallgatók munkáját, sajnos azonban nem feltétlenül nemes célokra használva az ott szerzett ismereteket. Azt gondoljuk, ezért mindenképpen érdemes vizsgálni e két témakör összefonódását. Ennek kapcsán nagy jelentőséget tulajdonítunk annak, hogy oktatóként milyen segítséget adunk, illetve milyen elvárásokat fogalmazunk meg diákjaink számára egyetemi tanulmányaik alatt, továbbá annak is, hogy milyen példát mutatunk munkánk során. Fontos az is, hogy diákjaink számára egyértelműen definiáljuk (akár velük megvitatva), hogy mit tekintünk csalásnak, ennek formáit az etikai kódexben konkrétan fektessük le. Érdemes azt is hangsúlyozni, hogy a tanórákon kívüli fórumokon is erősíteni kell bennük a szakma iránti helyes etikai attitűdök kialakítását. Bízunk benne, hogy tanulmányunk felhívta erre a nagyon fontos kérdéskörre az olvasó figyelmét, elindítva ezzel újabb tanulmányok és kutatások megszületését.

\section{Hivatkozások}

[1] Barizsné Hadházi Edit - Kiss Zsuzsanna, Hallgatók etikai attitűdvizsgálata, International Journal of Engineering and Management Sciences/Műszaki és Menedzsment Tudományi Közlemények, 2016, 1,

megtekinthető: http://ijems.lib.unideb.hu/cikk/cikk/57695b9692ac9 letöltés dátuma: 2017. március 10.

[2] Curren, M. T. - Harich, K. R., Business Ethics: A Comparison Of Business And Humanities Students And Faculty, Journal of Education for Business, 1996, 72/1, 9-12.

[3] Evans, J. D., Straightforward statistics for the behavioral sciences, Brooks/Cole Publishing, Pacific Grove, California, 1996

[4] Fülöp Márta, Verseny a társadalomban - verseny az iskolában, In: Benedek András - Hungler Diána szerk., 2008, VII. Nevelésügyi Kongresszus, Az oktatás közügy, Budapest, 51-74. 
[5] Lozier, K. A, Student Perceptions of Academic Dishonesty Scenarios, Honors Thesis, Ball State University, 2012, megtekinthető:

http://cardinalscholar.bsu.edu/handle/123456789/195858, letöltés dátuma: 2016. március 12.

[6] Ludlum, M. - Moskaloinov, S., Identifying Russia's Corruption Problem: A College Student Survey, Procedings of the Academy for Studies in International Business, 2009, 9/9.,17-21.

[7] Ludlum, M. - Moskaloinov, S. - Ramachandran, V., Examining Ethical Behaviors by Business Studenst, American International Journal of Contemporary Research, 2013, 3/3, 13-21.

[8] Ludlum, M. - Xu, W. - Ramachandran, V. - Teeman, J., Maturity, Gender, Parenthood and Ethical Orientation: A Three Campus Survey, Mustang Journal of Business and Ethics, 2015, 6, 67-78.

[9] McCabe, D. L. - Bowers, W. J., The relationship between student cheating and college fraternity or sorority membership. NASPA Journal, 1996, Vol. 33., No. 4., 280-291.

[10] McCabe, D. L. - Trevino, L. K., Academic Dishonesty: Honour Codes and Other Contextual Influences, The Journal of Higher Education, 1993, Vol. 64., No. 5., 522-538.

[11] McCabe, D. L. - Trevino, L. K., What We Know about Cheating in College, Change, 1996, 28/1, 28-33.

[12] McCabe, D.L., Trevino, L.K., \& Butterfield, K.D., Cheating in academic institutions: A decade of research, Ethics \& Behavior, 2001, 11(3), 219-232.

[13] Nemzeti Média és Hírközlési Hatóság, Lakossági internethasználat, Online piackutatás 2015, Kutatási jelentés az NMHH részére, Ariosz Kft., NRC Kft. megtekinthető: http://nmhh.hu/tart/index/575/Piackutatasok_tanulmanyok, letöltés dátuma: 2017. március 9.

[14] Orosz Gábor - Farkas Dávid, Csalás a középiskolában, Magyar Pszichológiai Szemle, 2011, Vol. 66. No. 4. 605-630.

[15] Sims, R. L., The Relationship Between Academic Dishonesty and Unethical Business Practices, Journal of Education for Business, 1993, 68/4, 207-211.

[16] Waples, E. P. - Antes, A. L. - Murphy, S. T. - Connelly, S. -Mumford, M. D., A Meta-Analytic Investigation of Business Ethics Instruction, Journal of Business Ethics, 2009, 87, 133-151. 